\title{
Keamanan Sepeda Motor Berbasis Kunci Rahasia Aplikasi Android Dan Sistem Mikroprosesor
}

\author{
Yusuf Normawan, Heru Supriyono \\ Program Studi Informatika \\ Universitas Muhammadiyah Surakarta (UMS) \\ Surakarta, Indonesia \\ Johnuchup@gmail.com, Heru.Supriyono@ums.ac.id
}

\begin{abstract}
Abstraksi-Seiring dengan semakin banyaknya tingkat produksi kendaraan bermotor saat ini, akan berimbas dengan meningkatnya tindak kriminalitas pencurian kendaraan bermotor. Penelitian ini bertujuan untuk membuat sistem keamanan tambahan berbasis Android dan Mikroprosesor. Perancangan sistem keamanan ini menggunakan metode eksperimental yaitu dengan cara melakukan percobaan langsung pada sepeda motor. Hasil yang di dapat dari sistem ini merupaakan sistem keamanan tambahan. Pengujian dilakukan dengan menggunakan Android yang dikoneksikan dengan Bluetooth HC-05, kemudian data perintah akan dibaca dan diproses oleh Arduino Uno yang akan mengontrol Relay Modul. Dari pengujian tersebut, motor bisa menyala dengan kondisi kuci kontak ON, Bluetooth HC-05 telah terkoneksi dengan Smartphone, dan data yang dimasukkan valid. Sedangkan Alarm akan berbunyi pada kondisi kontak $O N$, Bluetooth HC-05 telah terkoneksi dengan Smartphone, namun data yang dimasukkan tidak valid. Aplikasi ini merupakan sebuah sebuah sistem keamanan sepeda motor yang terintegrasi antara Smartphone dengan Arduino Uno yang telah diaplikasikan pada sebuah motor dengan melakukan verifikasi Username dan Password. .
\end{abstract}

Katakunci-lampu; android; arduino; sepeda motor; alarm;

\section{Pendahuluan}

Perkembangan teknologi yang sangat pesat saat ini membuat banyak orang menggunakannya untuk mempermudah pekerjaannya. Hal tersebut membuat Developer saling bersaing untuk mengembangkan rancangan bangun teknologinya. Berbagai macam teknologi telah muncul pada era saat ini. Sehingga, banyak bermunculan teknologi-teknologi mutakhir yang dapat mempermudah pekerjaan para penggunanya. Maka dari itu teknologi terbaik yang banyak dicari oleh kebanyakan pengguna dan juga memiliki kisaran harga yang dapat dijangkau.

Seiring dengan perkembangan teknologi pada saat ini, membuat orang-orang yang memahami kelemahan dari sebuah teknologi tersebut menyalahgunakannya. Hal ini menimbulkan tindak kriminalitas yang meningkat. Salah satunya adalah tindak kriminalitas pencurian kendaraan bermotor. Sistem keamanan yang diberikan dari produsen sepeda motor hanyalah sistem standar yaitu kunci kontak konvensional yang hanya digunakan sebagai penghubung dan pemutus arus listik dari akumulator menuju sitem pengapian mesin sepeda motor.

Berdasarkan data yang dimiliki oleh Polresta Tegal, tercatat bahwa pada tahun 2017 terdapat 181 kasus curanmor yang telah dilaporkan. Meskipun kasus curanmor pada tahun 2017 mengalami penurunan dibanding tahun 2016 yang mencapai angka 199 kasus curanmor, hal ini belum dapat membuat pemilik kendaraan bermotor merasa tenang. Tidak hanya merusak rumah kunci kontak dengan menngunakan kunci T, sekarang ini modus curanmor sangat bervariasi. Salah satunya adalah menggunakan cairan kimia yang dituangkan kedalam rumah kunci kontak. Cara ini akan lebih menghaluskan aksi pencuriaan para pelaku curanmor tanpa dicurigai oleh warga di sekitar mereka saat beraksi.

Dilihat dari hal di atas, maka diperlukan adanya variasi guna meningkatan sistem keamanan pada sepeda motor. Salah satu sistem keamanan yang dapat diterapkan adalah sistem keamanan sepeda motor berbasis kunci rahasia aplikasi android dan sistem mikroprosesor. Sistem ini adalah penggabungan antara Hardware dan Software yang diaplikasikan pada sepeda motor tersebut. Sistem keamanan ini menggunakan Arduino Uno sebagai mikroprosesor, Android sebagai sistem operasi dan Bluetooth sebagai media transmisi.

Menurut Muchtar \& Firdaus (2017) Arduino Uno merupakan sebuah papan elektronik mikrokontroler yang didasarkan pada Hardware ATMEGA328 dan juga memiliki 14 pin input dan output. Arduino Uno ini merupakan platform elektronik open source yang berbasis pada Software dan Hardware yang dirancang untuk memudahkan para penggunanya dalam mengembangkan teknologi elektronik yang diinginkannya.

Menurtut Kholilah \& Tahtawi (2016) menjelaskan bahwa Bluetooth merupakan perangkat yang digunakan sebagai media transmisi antara satu perangkat dengan perangkat lainnya yang telah terpasang Bluetooth. Pada sistem yang dibuat kali ini, penulis menggunakan Modul Bluetooth HC-05 sebagai media transmisi tanpa menggunakan kabel (wireless) antara Smartphone dengan mikroprosesor. Modul Bluetooth ini dapat langsung diintegrasikan dengan Arduino Uno melalui pin yang telah tersedia. 
Kamelia dkk (2014) menjelaskan bahwa sekarang ini ponsel yang banyak digunakan oleh masyarakat adalah Smartphone. Smartphone menawarkan fitur-fitur yang lebih canggih dari pada polsel lama antara lain monophonic, pholyphonic yang masih menggunakan sistem operasi java dan symbian. Pratama (2016) menjelaskan bahwa Android adalah sebuah sistem operasi yang berbasis Linux pada Smartphone dan juga komputer tablet. Android menyediakan platform open source bagi para pengembang untuk menciptakan aplikasinya sendiri.

Tharisny, dkk (2016) menjelaskan bahwa MIT App Inventor merupakan suatu alat pemrograman yang memudahkan penggunanya dalam pembuatan sebuah aplikasi Android dengan menggunakan sistem drag and drop perintah yang telah disediakan oleh alat tersebut.

Setyawan (2018) pernah menggunakan sistem keamanan tambahan sepeda motor berbasis mikrokontroler. Namun menggunakan RFID ssebagai kunci tambahan dari sepeda motor tersebut.

Berdasarkan permasalahan tersebut, maka penulis membuat inovasi sistem keamanan sepeda motor dengan menggunakan Android sebagai pengendali Arduino Uno dari jarak jauh yang telah diimplementasikan pada sebuah sepeda motor. Dalam hal ini dimaksudkan untuk menambah sistem keamanan sepeda motor pada saat ini.

\section{METODE}

Perancangan sistem keamanan ini menggunakan metode eksperimental yaitu dengan cara melakukan percobaan langsung pada sepeda motor. Dalam pembuatan sistem ini, terdapat beberapa tahapan yaitu analisis kebutuhan, perancangan perangkat keras dan perangkat lunak serta pengujian sistem. Tahapan tersebut dapat dilihat pada Gambar 1.

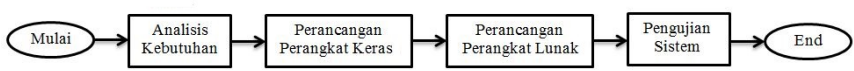

Gambar 1. Diagram alir pada proses penelitian

\section{A. Analisis Kebutuhan}

Tahapan pertama dalam analisis ini adalah kebutuhan yang dibutuhkan dalam perancangan sistem keamanan sepeda motor yang meliputi kebutuhan perangkat keras dan kebutuhan perangkat lunak yang dibutuhkan.

a) Kebutuhan Perangkat Keras

Pada tahap ini penulis menggunakan berbagai instrumen yaitu:

1. Laptop Lenovo G40-45 (AMD A8-6410, 2.40 GHz, 500 GB HDD, 4 GB RAM)

2. Smartphone Android (Redmi 2 Prime dengan Operating System Kitkat 4.4.4) sebagai perangkat untuk mengontrol mikroprosesor dari jarak jauh melalui User Interface (UI) yang telah dibuat

3. Papan Arduino UNO R3 sebagai mikroprosesor pengolah data yang dikirim oleh Smartphone yang telah diaplikasikan pada sepeda motor

4. Modul Bluetooth HC-05 sebagai media penerima data yang dikirim melalui Bluetooth oleh Smartphone

5. Relay 2 Channel sebagai saklar pemantik kondisi motor dari data yang dikirim oleh Arduino UNO R3

6. USB multi-charger motor waterproof sebagai pengubah arus DC motor

7. Kabel Serial Arduino to PC sebagai media untuk berkomunikasi antara Laptop dengan mikroprosesor

8. Flasher sebagai alat agar suara alarmnya bisa berkedip

9. Kabel body

10. ACCU motor sebagai power supply

b) Kebutuhan Perangkat Lunak

Pada tahap kebutuhan perangkat lunak ini, penulis menggunakan menggunakan berbagai sofware yaitu:

1. Arduino IDE guna mengontrol jalannya sistem sesuai dengan alur diagram dengan menggunakan bahasa pemrograman $\mathrm{C}$

2. MIT App Inventor dalam pembuatan User Interface (UI)

3. Software Fritzing sebagai perancaangan desain alat yang akan dibuat

4. Web online draw.io untuk pembuatan blok diagram

\section{B. Perancangan Perangkat Keras}

Pada tahap kedua yaitu perancangan perangkat keras, penulis menggunakan Arduino sebagai mikroprosesor dan komponen lainya yang telah diaplikasikan pada sebuah motor. Sketsa rangkaiannya dapat dilihat pada Gambar 2, sedangkan sketsa rancangan perangkat keras dapat dilihat pada Gambar 3. 


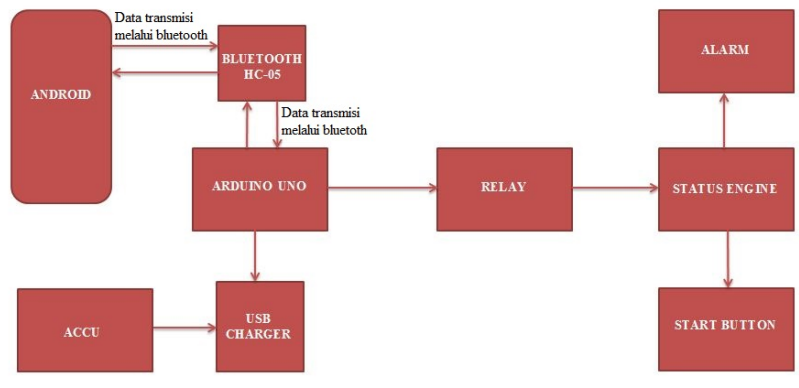

Gambar 2. Sketsa rangkaian keseluruhan perangkat keras

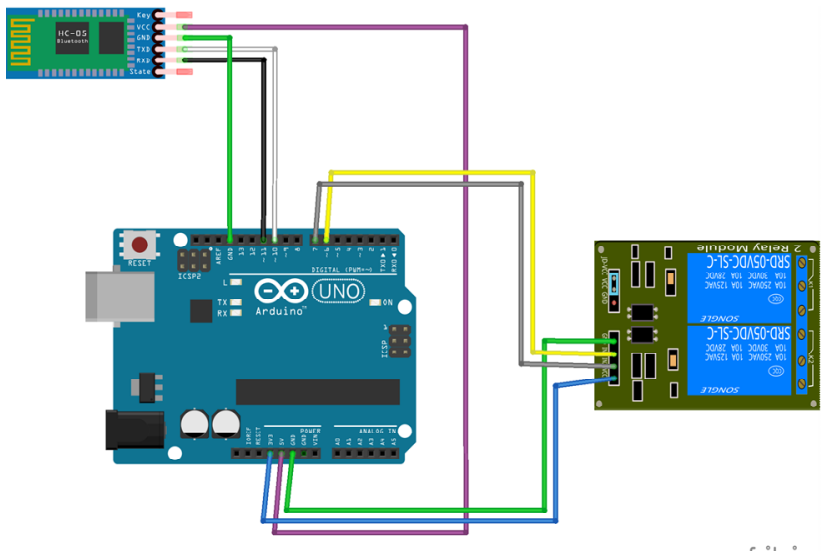

Gambar 3. Diagram skematik

Dilihat dari diagram skematik di atas, terdapat beberapa pin yang dijelaskan pada Gambar 1 dan 2.

Tabel ।. Pin Out Bluetooth HC-05

\begin{tabular}{|c|c|}
\hline Bluetooth HC-05 & Arduino Pin \\
\hline Rx (Hitam) & 11 \\
\hline Tx (Putih) & 10 \\
\hline Gnd (Hijau) & Gnd \\
\hline Vcc (Ungu) & $5 \mathrm{v}$ \\
\hline
\end{tabular}

Tabel r. Pin out Relay Module

\begin{tabular}{|c|c|}
\hline Relay Module & Arduino Pin \\
\hline IN1 (Kuning) & 6 \\
\hline IN2 (Abu-abu) & 7 \\
\hline Vcc (Biru) & $3.3 \mathrm{v}$ \\
\hline Gnd (Hijau) & Gnd \\
\hline
\end{tabular}

\section{Perancangan Perangkat Lunak}

Tahap berikutnya adalah perancangan perangkat lunak. Pada tahap ini terdapat dua perancangan yaitu perancangan UI dan perancangan Arduino IDE. Perancangan UI dengan menggunakan MIT App Inventor yang diaplikasikan pada Android yang dirancang sebagai pengirim data menuju mikroprosesor. Flowchart dari perancangan UI dapat dilihat pada Gambar 4, blok kode dari MIT App Inventor dapat dilihat pada Gambar 5 dan kode program dari Arduino IDE dapat dilihat pada Gambar 6. Selanjutnya perancangan perintah logika pada Arduino UNO dengan menggunakan Arduino IDE. Perancangan perintah logika pada Arduino ini dimaksudkan untuk dapat menerima dan mengolah data yang telah dikirim oleh Android yang telah terinstall aplikasi atau UI di atas melalui media transmisi bluetooth.

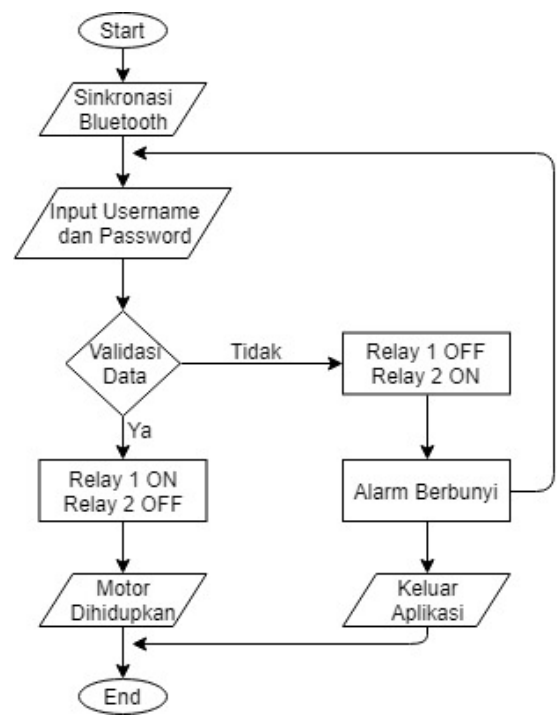

Gambar 4. Flowchart User Interface

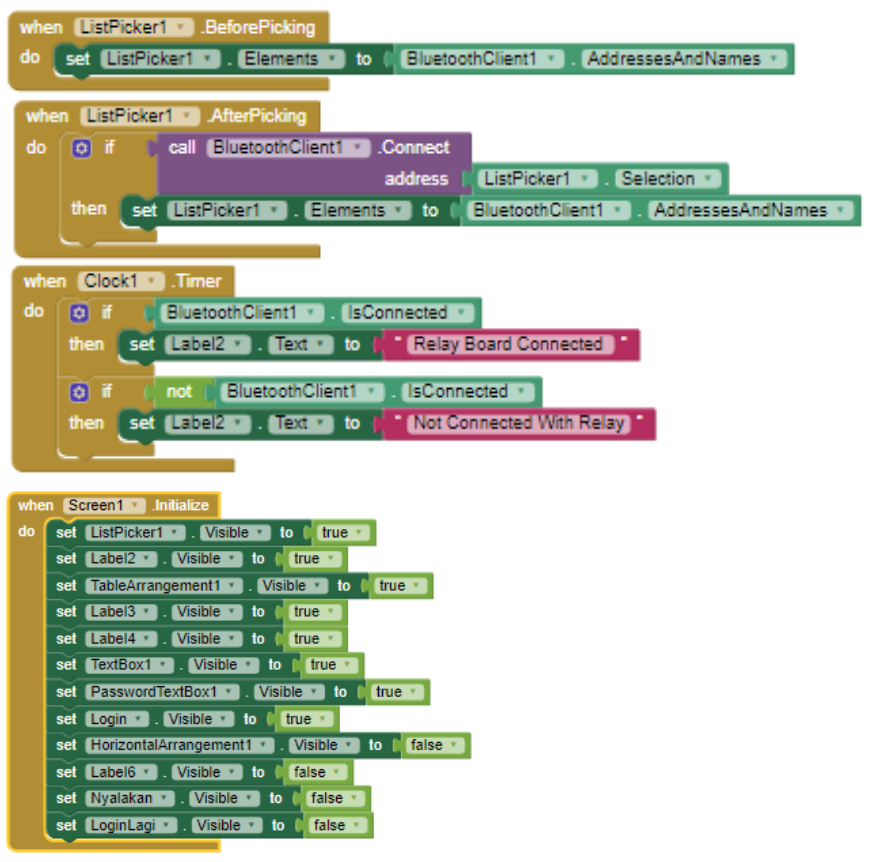

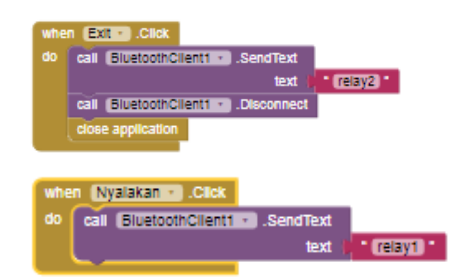




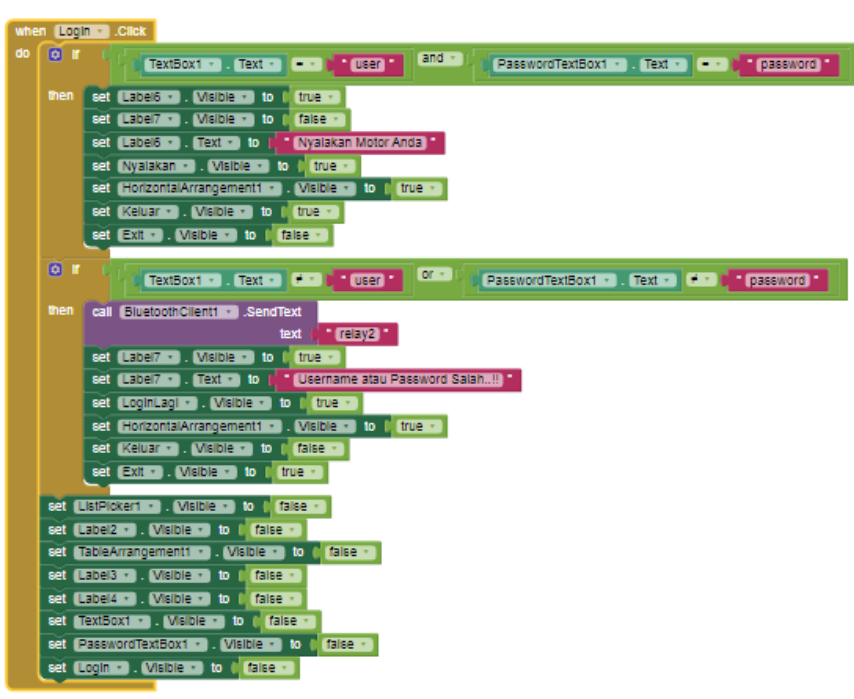

Gambar 5. Blok kode dari App Inventor

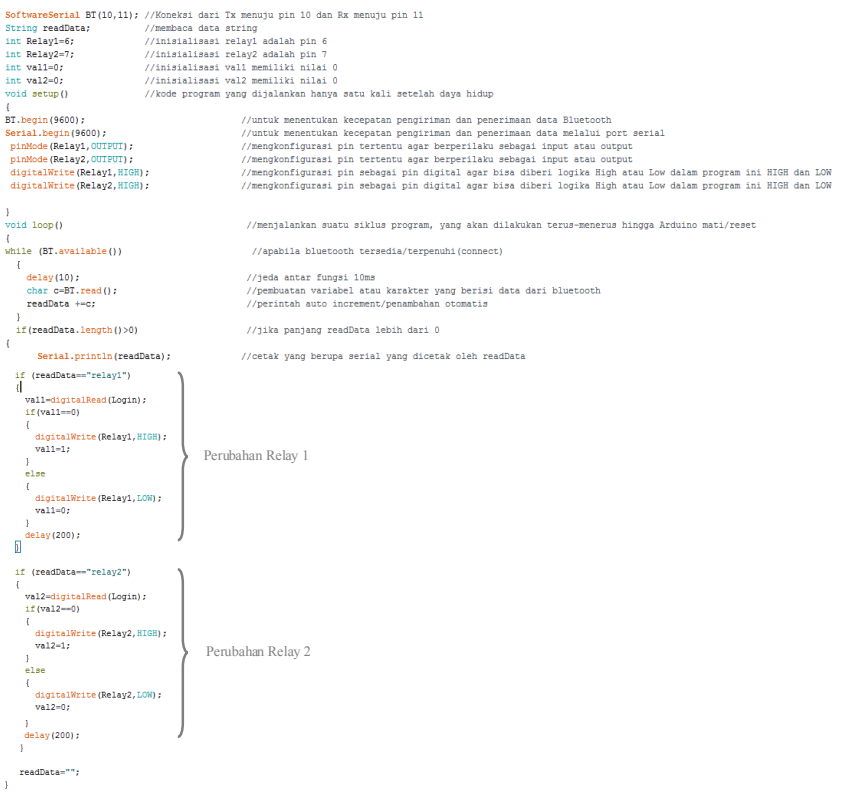

Gambar 6. Kode program dari Arduino IDE

\section{Pengujian Sistem}

Tahap terakhir dalam perancangan sistem ini adalah pengujian sistem baik perangkat lunak maupun perangkat keras, untuk mengetahui apakah sistem sudah sesuai dengan diagram alir yang dibuat. Pengujian pada perangkat keras ini meliputi ada kendala atau tidaknya komunikasi antara Android, Arduino dan sepeda motor. Sedangkan untuk perangkat lunak pengujian menggunakan Aruino IDE untuk melihat apakah terdapat kesalahan atau tidaknya pada sistem tersebut.

\section{HASIL DAN PEMBAHASAN}

\section{A. Instalasi Dan Konfigurasi}

UI dari sistem ini dibuat dengan menggunakan MIT App Inventor, sedangkan pembuatan kode program pada Arduino menggunakan Arduino IDE. Tampilan aplikasi yang telah dibuat dapat dilihat pada Gambar 7. Tampilan paling kiri merupakan tampilan awal dari aplikasi. Pada tampilan ini user diminta untuk menyambungkan bluetooth, mengisi username dan password kemudian klik pada tombol Login. Adanya sistem Login ini dimaksudkan untuk menambahkan tingkat keamanan pada aplikasi ini. Jika username dan password benar maka akan muncul tampilan seperti pada gambar di tengah dan jika salah akan muncul tampilan sesuai pada gambar paling kanan. Pada aplikasi ini, username yang dipakai adalah "user". Sedangkan password yang dipakai adalah "password".
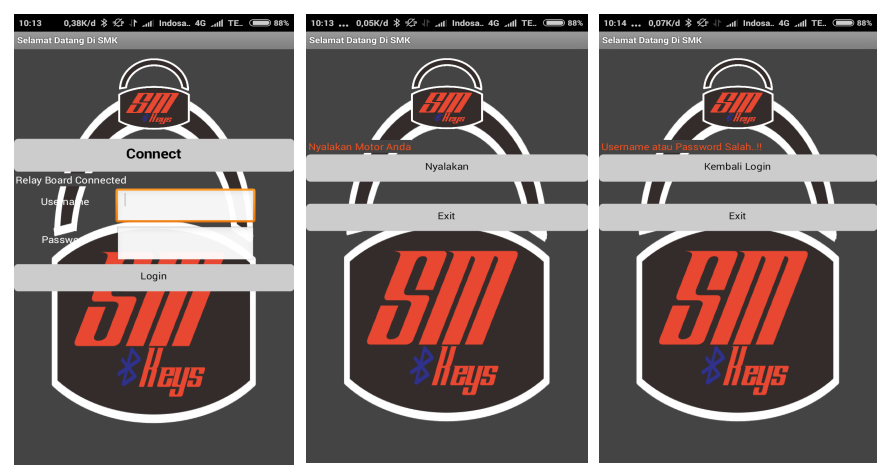

Gambar 7. Tampilan UI pada sistem ini

Sedangkan untuk sistem embedded, dimulai dari perakitan Arduino, Bluetooth HC-05, Relay dan USB charger. Setelah selesai dirakit, rangkaian tersebut diimplementasikan pada sepeda motor Honda Tiger Revo 2007. Arus yang dihasilkan ACCU merupakan arus DC. Sehingga arus DC (searah) yang dihasilkan ACCU, tegangan listrik akan dirubah mengggunakan USB Multy-Charger menjadi arus AC (bolakbalik). Rangkaian sistem embedded dapat dilihat pada Gambar 8 dan 9.

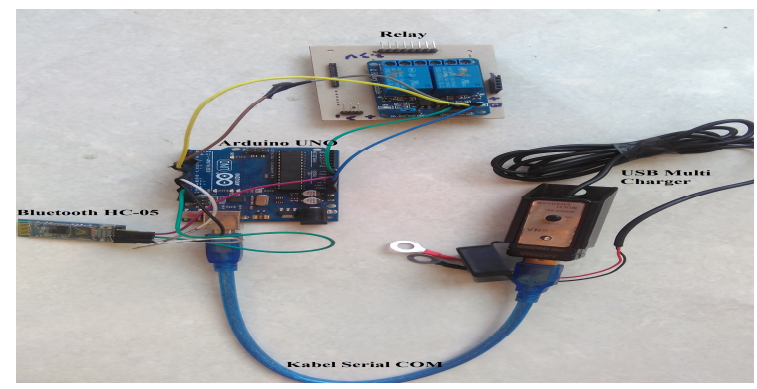

Gambar 8. Rangkaian sistem embbeded

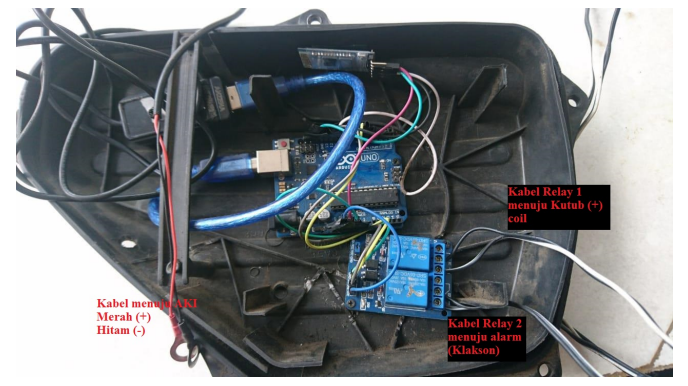


Gambar 9. Rangkaian sistem embbeded yang telah diaplikasikan pada sepeda motor

\section{B. Pengujian Komunikasi Bluetooth}

Dari sistem ini, didapati hasil dari uji sistem yang tercantum pada Tabel 3 dan 4. Pada Tabel 3 akan menampilkan jarak maksimal yang dapat dijangkau dari koneksi antara Bluetooth HC-05 dan Smartphone, dengan keterangan $\mathrm{OK}$ (terhubung) dan NO (tidak terhubung). Untuk Tabel 4, akan menampilkan pengujian sistem dari berbagai kondisi. Pada Tabel 5 akan menampilkan pengujian koneksi dengan berbagai hambatan. Estimasi biaya yang dikeluarkan dalam pembuatan sistem ini dapat dilihat pada Tabel 6 .

Tabel r. Pengujian Jarak Maksimal Yang Dapat Dijangkau

\begin{tabular}{|c|c|}
\hline Jarak & Hasil \\
\hline 0 meter & OK \\
\hline 3 meter & OK \\
\hline 6 meter & OK \\
\hline 9 meter & OK \\
\hline 10 meter & OK \\
\hline 11 meter & NO \\
\hline 12 meter & NO \\
\hline
\end{tabular}

Tabel Ł. Pengujian Sistem Dalam Berbagai Kondisi

\begin{tabular}{|c|c|}
\hline Kondisi & Uraian \\
\hline Kunci Kontak ON & $\begin{array}{l}\text { Hanya aksesoris motor saja yang } \\
\text { menyala (Indikator spedometer, } \\
\text { sein,klakson, lampu). Mesin tidak } \\
\text { dapat menyala, karena arus aki yang } \\
\text { akan masuk ke CDI telah diputus oleh } \\
\text { relay 1. }\end{array}$ \\
\hline $\begin{array}{l}\text { Kunci Kontak ON, username dan } \\
\text { password benar }\end{array}$ & $\begin{array}{l}\text { Aksesoris motor menyala, mesin } \\
\text { menyala ketika distarter. Hal ini terjadi } \\
\text { karena, relay } 1 \text { (sebagai pemutus arus } \\
\text { akike cdi) telah menyala. Sehingga } \\
\text { arus listrik dari aki menuju CDI telah } \\
\text { mengalir. }\end{array}$ \\
\hline $\begin{array}{l}\text { Kunci Kontak ON, username dan } \\
\text { password salah }\end{array}$ & $\begin{array}{l}\text { Aksesoris menyala, mesin mati, alarm } \\
\text { menyala. Hal ini terjadi karena relay } 2 \\
\text { dalam posisi menyala. }\end{array}$ \\
\hline $\begin{array}{l}\text { Kunci Kontak OFF, username dan } \\
\text { password benar }\end{array}$ & $\begin{array}{l}\text { Aksesoris tidak menyala, mesin tidak } \\
\text { menyala, alarm tidak menyala. }\end{array}$ \\
\hline \multicolumn{2}{|c|}{$\begin{array}{c}\text { Tabel ॰. Perbandingan Waktu Menghidupkan Secara Manual } \\
\text { Dan Menggunakan Sistem }\end{array}$} \\
\hline Kondisi & \begin{tabular}{|c|} 
Hasil \\
\end{tabular} \\
\hline $\begin{array}{l}\text { Sepeda motor berada di dalam garasi, } \\
\text { smartphone di luar garasi dalam } \\
\text { keadaan terhalang pintu garasi }\end{array}$ & Bluetooth terbaca, dapat terhubung \\
\hline $\begin{array}{l}\text { Sepeda motor berada di dalam garasi, } \\
\text { smartphone di luar garasi dalam } \\
\text { keadaan terhalang tembok }\end{array}$ & $\begin{array}{l}\text { Bluetooth terbaca, tidak dapat } \\
\text { terhubung }\end{array}$ \\
\hline $\begin{array}{l}\text { Sepeda motor berada di halaman } \\
\text { rumah, smartphone di luar gerbang } \\
\text { dalam keadaan terhalang gerbang } \\
\text { rumah }\end{array}$ & Bluetooth terbaca, dapat terhubung \\
\hline $\begin{array}{l}\text { Terdapat beberapa koneksi bluetooth } \\
\text { lain yang terdeteksi }\end{array}$ & Bluetooth terbaca, dapat terhubung \\
\hline
\end{tabular}

Tabel ч. Estimasi Biaya Yang Dikeluarkan

\begin{tabular}{|c|c|c|c|}
\hline Nama Alat & Harga Satuan & Jumlah & Total \\
\hline Arduino UNO R3 & $\operatorname{Rp} 83.000,00$ & 1 buah & $\operatorname{Rp} 83.000,00$ \\
\hline $\begin{array}{l}\text { Kabel Serial Arduino to } \\
\text { PC }\end{array}$ & $\operatorname{Rp} 12.500,00$ & 1 buah & Rp $12.500,00$ \\
\hline Bluetooth Modul HC-05 & Rp 55.000,00 & 1 buah & Rp 55.000,00 \\
\hline Relay Modul 2 Channel & $\operatorname{Rp} 23.000,00$ & 1 buah & $\operatorname{Rp} 23.000,00$ \\
\hline $\begin{array}{l}\text { USB Multi-charger motor } \\
\text { waterproof }\end{array}$ & $\mathrm{Rp} 70.000,00$ & 1 buah & Rp $70.000,00$ \\
\hline Flasher & $\mathrm{Rp} 15.000,00$ & 1 buah & $\mathrm{Rp} 15.000,00$ \\
\hline Kabel Jumper & Rp 700,00 & 10 buah & Rp 7.000,00 \\
\hline Kabel Body & $\begin{array}{c}\mathrm{Rp} 7.000,00(1 \\
\mathrm{m})\end{array}$ & $2,5 \mathrm{~m}$ & $\mathrm{Rp} 17.500,00$ \\
\hline \multicolumn{3}{|c|}{ Total } & $\operatorname{Rp} 283.000,00$ \\
\hline
\end{tabular}

\section{PENUTUP}

Dari hasil pembuatan Tugas Akhir ini dapat ditarik kesimpulan sebagai berikut:

a. MIT App Inventor dapat digunakan untuk membuat aplikasi Android pengontrol Arduino UNO yang telah diimplementasikan pada sepeda motor

b. Jarak maksimal koneksi antara Smartphone dengan Bluetooth $\mathrm{HC}-05 \pm 10$ meter

c. Kontak motor adalah sebagai kunci utama dari sepeda motor tersebut dan sistem ini hanya sebagai keamanan tambahan saja

Saran untuk pengembang dari pembuatan sistem ini adalah dapat mengganti media transmisi data menggunakan media lain. Dapat menambahkan fitur GPS supaya dapat mendeteksi posisi motor berada di mana.

\section{Daftar Pustaka}

[1] Kholilah, Ika., \& Al Tahtawi, Adnan Rafi. 2016. Aplikasi ArduinoAndroid untuk Sistem Keamanan Sepeda Motor. JTERA - Jurnal Teknologi Rekayasa, 1(1), 53-58. ISSN : 2548-737X

[2] Muchtar, Husnibes., \& Firdaus, Bayu. 2017. Perancangan Sistem Keamanan Tambahan pada Kendaraan Sepeda Motor Berbasis Aplikasi Android dengan Menggunakan Mikrokontroller. Seminar Nasional Sains dan Teknologi 2017 Fakultas Teknik Universitas Muhammadiyah Jakarta. p- ISSN : 2407 - 1846 e-ISSN : $2460-8416$.

[3] Pratama, D., Hakim, D. A., Prasetya, Y., Febriandika, N. R., Trijati, M., \& Fadilah, U. (2016). Rancang Bangun Alat dan Aplikasi untuk para Penyandang Tunanetra Berbasis Smartphone Android. Jurnal Khazanah Informatika, 14-19

[4] Priyanto, Mamdukh Adi. 2018. Angka Kejahatan di Kota Tegal Selama 2017 Alami Penurunan, Curanmor Masih Mendominasi. http://jateng.tribunnews.com/2018/01/01/angka-kejahatan-di-kota-tegalselama-2017-alami-penurunan-curanmor-masih-mendominasi

[5] Supriyono, H. \& Setyawan. A. D. N. (2016). Perancangan Imobilizer Berbasis RFID untuk Sepeda Motor. Jurnal Emitor, Vol 16, No.2

[6] Kamelia, L., Noorhassan, A., Sanjaya, M., \& Mulyana, E. (2014). DoorAutomation System Using Bluetooth-Based Android For Mobile Phone. ARPN Journal of Engineering and Applied Sciences, Vol 9, No 10

[7] Tharishny, S., Selvan, S., \& Nair, P. (2016). Android based Smart House Control via Wireless Communication. International Journanl of Scientific Engineering and Technology, (5), 323-325 